\title{
ASSESSMENT OF INFLUENTIAL FACTORS FOR PURCHASING GENT'S SHOES - UNDERSTAND- ING THE BASIC COMFORT PROPERTIES
}

\author{
Amal KANTI DEB ${ }^{*}$, Md. Aftab ALI SHAIKH, Md. Rayhan SARKER, Md. Israil HOSSAIN \\ Institute of Leather Engineering and Technology, University of Dhaka, Dhaka-1209, Bangladesh, email: debak.707@gmail. \\ com, aftabshaikh@du.ac.bd, md.sarkerdu.rayhan@gmail.com, israil.rafi@yahoo.com
}

Received: 30.08.2017

Accepted: 16.02 .2018

https://doi.org/10.24264/Ifj.18.1.2

ASSESSMENT OF INFLUENTIAL FACTORS FOR PURCHASING GENT'S SHOES - UNDERSTANDING THE BASIC COMFORT PROPERTIES ABSTRACT. There are many factors that have a great influence over customer's decision in case of choosing gent's shoes and also several features are related to comfort properties of shoes. The aim of the study was to identify the most influential purchase factors of gent's shoes along with disclosing frequently considered comfort factors through target sample population and experts. Two questionnaire experiments were performed among selected respondents and four experts' opinions were observed. The number of total interviewees who provided their preference of choosing factors during shoe purchase was 72 and the interviewees gave their feedbacks especially on basic comfort properties after wearing three pairs of sample shoes for a period of two months. Bar chart, pie chart, Pareto analysis and average weighted method were followed for assessing data. Style, comfort, price and colour were the top four factors that were suggested by the respondents respectively and style, comfort, color and price were considered by the experts at the time of purchasing new shoes, respectively. On the other hand, breathability, proper size and fit, light weight, flexibility and appearance were selected as the most considered factors regarding shoe comfort, whereas experts suggested size and fit, cushioning, flexibility, light weight, breathability, arch support and toe profile shape, respectively. Those who wore sample shoes made of synthetic upper materials and narrow fitted in the forefoot region during the experimental period, tended to perceive them as very uncomfortable.

KEY WORDS: comfort, preference, shoe, style

\section{EVALUAREA FACTORILOR CE INFLUENTEAZĂ ACHIZITIONAREA ÎNCĂLJĂMINTEI PENTRU BĂRBATI - ÎNTELEGEREA PROPRIETĂTILOR DE} BAZĂ CE TIN DE CONFORT

REZUMAT. Există mulţi factori care au o mare influenţă asupra deciziei clientului în cazul alegerii încălţămintei pentru bărbaţi şi multe caracteristici sunt legate de proprietăţile de confort ale încălţămintei. Scopul acestui studiu a fost de a identifica cei mai influenţi factori în achiziţionarea unei perechi de pantofi pentru bărbaţi, dezvăluind totodată factorii legaţi de confort cel mai des luaţi în considerare de un eşantion ţintă al populaţiei şi de experţi. S-au efectuat două experimente cu chestionare adresate respondenţilor selectaţi şi s-au luat în considerare opiniile a patru experţi. Numărul total de persoane intervievate care şi-au expus preferinţele privind factorii de decizie în procesul achiziţionării pantofilor a fost de 72 , iar persoanele intervievate au oferit feedback în special cu privire la proprietăţile de bază ce ţin de confort, după ce au purtat trei perechi de pantofi de probă timp de două luni. Metodele utilizate pentru evaluarea datelor au fost diagrama cu bare, diagrama cu structură radială, analiza Pareto şi media ponderată. Stilul, confortul, preţul şi culoarea au fost primii patru factori indicaţi de respondenţi, iar stilul, confortul, culoarea şi preţul au fost considerate de experţi la momentul achiziţionării unor pantofi noi. Pe de altă parte, permeabilitatea vaporilor de apă, dimensiunea corespunzătoare şi potrivirea, greutatea redusă, flexibilitatea şi aspectul au reprezentat cei mai apreciaţi factori în ceea ce priveşte confortul pantofilor, iar experţii au luat în considerare dimensiunea şi potrivirea, capacitatea de amortizare a şocurilor, flexibilitatea, greutatea redusă, permeabilitatea la vapori de apă, suportul plantar şi forma profilului. Pantofii de probă cu feţe din materiale sintetice şi strâmţi în regiunea antepiciorului purtaţi în perioada experimentală au fost percepuţi ca fiind foarte incomozi. CUVINTE CHEIE: confort, preferinţă, încălţăminte, stil

\section{L'ÉVALUATION DES FACTEURS QUI INFLUENCENT L'ACHAT DES CHAUSSURES POUR HOMME - COMPRENDRE LES PROPRIÉTÉS DE CONFORT DE BASE}

RÉSUMÉ. Il y a beaucoup de facteurs qui ont une grande influence sur la décision du client dans le cas de choisir des chaussures pour homme et également plusieurs caractéristiques sont liées aux propriétés de confort des chaussures. Le but de cette étude a été d'identifier les facteurs les plus influents dans l'achat d'une paire de chaussures pour hommes, tout en révélant les facteurs de confort le plus souvent pris en compte par un échantillon cible de la population et par des experts. On a mené deux expériences à partir d'un questionnaire avec la participation des répondants sélectionnés et les opinions de quatre experts ont été prises en compte. Le nombre total de personnes interviewées sur leur préférences des facteurs de choix lors de l'achat de chaussures a été 72 et les personnes interviewées ont donné leur avis sur les propriétés de confort de base après avoir porté trois paires d'échantillons de chaussures pendant deux mois. Les méthodes utilisées pour évaluer les données ont été le diagramme à barres, le diagramme à secteurs, l'analyse de Pareto et la moyenne pondérée. Le style, le confort, le prix et la couleur ont été les quatre principaux facteurs suggérés par les répondants tandis que le style, le confort, la couleur et le prix ont été pris en compte par les experts lors de l'achat de nouvelles chaussures. D'autre part, la respirabilité, la taille et l'ajustement appropriés, le poids léger, la flexibilité et l'apparence ont été les facteurs les plus appréciés pour le confort des chaussures, tandis que les experts ont suggéré la taille et l'ajustement, la capacité d'absorption des chocs, la flexibilité, la légèreté, la respirabilité, le support plantaire et la forme de profil. Ceux qui ont porté des échantillons de chaussures au tiges en matériaux synthétiques et étroits dans la région de l'avant-pied pendant la période expérimentale, les ont perçu comme très inconfortables.

MOTS CLÉS: confort, préférence, chaussure, style * Correspondence to: Amal Kanti DEB, Institute of Leather Engineering and Technology, University of Dhaka, Dhaka-1209, Bangladesh, email:
debak.707@gmail.com 


\section{INTRODUCTION}

Nowadays, a pair of shoes is not only used for its functional value but also for its fashion attributes. Since the foot has the most functional movement among our body organs, it should be protected in a hygienic way, for which appropriate footwear is needed. Well fitting, fit for purpose, supportive shoes which allow normal foot function, stable heel height of approximately 25 $\mathrm{mm}$, adequate width and depth, outsole grip, flexible uppers and inshoe climate are the most considered factors for appropriate footwear [1]. Though footwear is a consumable good, it has no proper labeling on it which is generally used for many consumable goods to prescribe the quality information and constituents of particular goods in Bangladesh. That is why it makes a great puzzle for footwear customers of Bangladesh what they are buying, what the quality they are absorbing, as many artificial and synthetic leathers as well as fibers are now inundated in the footwear market for its low price. According to EU Directive No.94/11/EC [2], shoe materials information such as natural leather, natural leather with covering, artificial leather, textile material or synthetic material on the labeling of the product should be transcribed which is followed in the EU member states. Moreover, it is very essential to provide adequate information to the customers about the product features that will help them in purchasing their intended shoes. Customers usually consider different factors for choosing new shoes during purchase. They are intentionally or unintentionally influenced by these factors during the selection of a new shoe. At present, comfort features are widely searched for footwear, garments and apparel but what should be actually delved into the footwear for comfort features are mostly obscure to the general customers. For this reason, it was the part of this research to disclose the comfort features perceived by the customers along with experts' review in order to get reliable information. Through this study, footwear purchasing decision factors and comfort features considered by the respondents will be revealed and also experts' opinions will be extracted regarding these issues. Customers will be aware of the factors which should be considered as priority basis and gathered initial knowledge about the essential properties of comfort shoes which will make them able to differentiate between the basic comfort and discomfort properties of shoes that should be considered at the time of purchasing new shoes. Along with these, shoe manufacturers would find the customers' opinions as well as experts' suggestions with respect to various factors of shoe and their intended comfort features which will help them to develop new shoes successfully. There are different factors that may play a pivotal role in case of purchasing shoes; such as comfort, style, price, color, brand, outlook, upper material, weight, safety, heel height, don on \& off and outsole material etc. Comfort properties are all about sensation, which can vary from person to person. Comfort can be prescribed as a feeling of relaxation and well-being [3]. Goonetilleke addressed comfort with respect to positive sensation [4]. Footwear comfort feature depends on many factors comprising material properties of shoe [5], shoe style, shoe fit $[6,7]$ and psychological factors, all of which have significant importance towards imparting sensation. At present, there are many synthetic materials being used in footwear industries along with leather. Being a natural material, leather has porous structure which makes it convenient for breathability and for this reason leather shoe has a great preference over synthetic shoe in case of comfort features. Casual and Moccasin shoes are more popular among the young users and these shoes are unlaced with more opening area and also considered as more comfortable shoes than that of any other styles. The core focus of this study was to unveil the factors that influence the decision of a customer during shoe purchase, to investigate the aspects that make shoe comfortable along with experts' investigations.

\section{Literature Review}

The decision of purchasing new shoes and comfort features can vary from one's to other's choice according to their needs, ages, health conditions, life styles, regions and living weather conditions. Particular style may affect the customers such as if one wants to buy running or dress shoes, so there will be some difference of intended comfort features and purchasing decision factors. Product consumption and purchasing decisions are 
influenced by the benefits that is found from the quality of goods [8]. Four factors are found such as comfort, aesthetics, perspiration and belief as the general criteria related to buying decision, and tactile (size, texture, feeling inside the shoe, and inside shoe climate), auditory (sound produced) and olfactory (unpleasant odors) senses are the main differences between comfortable and uncomfortable shoes [9]. In another study, style pattern, color of footwear, material used, brand and comfort by product used, durability of product, service and warranty given were identified as the influencing factors for purchasing shoes [10]. A survey conducted at Karachi revealed that price and quality are the most influential factors on consumer preference and purchasing intention [11]. Five key characteristics such as minimal heel to toe drop, neutral (shoes do not contain stability or motion control elements that interfere with normal foot motion), relatively light weight, wide toe box and optimum cushioning are the most considered features for running shoes [12]. Arch type compatibility with shoe design is also among the most considered factors for running shoes [13]. On the other hand, many people affected with stroke and Parkinson's were found to be comfortable with slippers indoors, whereas excessive heel height, reduced friction on the soles of footwear, walking barefoot, wearing socks or footwear with a flimsy sole were found as the most injurious factors for older people [14]. Therefore, it is very clear that comfort features and purchasing decision can vary from one customer to another. Environmental conditions and individual characteristics of the consumer are closely related with the feeling of comfort and discomfort $[15,16]$. Comfort, fit, support, heel height, don on/off and weight are the most frequent considered factors for choosing shoes and heel rigidity and sole hardness are the poor characteristics for any kind of footwear [17]. Consumers' subjective feelings, ambient factors (temperature, humidity etc), hygiene properties (hygroscopicity, moisture return, wetting, capillarity and breathability) are the crucial factors for comfortable and uncomfortable shoes [18]. Pressure distribution is another considered factor for shoe comfort, peak pressure and perceived comfort has a negative correlation across the entire surface of the foot [19]. Several studies were conducted in order to know the purchasing factors and comfort features through survey study and wearing sample shoes but there is lack of experts' opinions in these studies and no preference ranking was established. An interactive survey study, feedbacks from respondents after wearing sample shoes and experts' opinions were conducted in this study in order to get a better result which will fill up the gap of the previous studies. Moreover, since purchasing factors and comfort features may vary from one country to another and there was no research about finding these factors in Bangladesh, this research will contribute a significant role to know about customers' behavior and customers will be able to know the important factors related shoe comfort and what they should search for purchasing shoes, from the experts' perspective. On the contrary, manufacturers will get a comprehensive guide line for producing comfort shoes and they will know more about how to satisfy customers' demand.

\section{MATERIALS AND METHOD}

The followed method of this research can be subdivided into two categories; such as interactive survey for finding purchasing factors as well as comfort features wearing sample shoes by the participants and experts' review about these factors to find a preferred ranking of these factors. The first experiment was carried out in the Dhaka city of Bangladesh among 72 male sample population who had at least 3 pairs of shoes. The sample population was selected equally from students and professional persons whose age range was 24 to 32 years and mean age was 27.4 years. All of the participants were related with footwear professions or leather/ footwear backgrounder students. The sample population was targeted considering the highest volume of youth against the total population of the country who used to prefer wearing casual and/or moccasin shoes. The sample shoes had been worn alternatively by the participants during an experimental period of two months from $20^{\text {th }}$ April to $18^{\text {th }}$ June, 2017 and feedbacks were collected after the experimental period. Then two academic and two industrial experts were requested for their reviews on shoe purchasing decision factors and comfort features 
in order to get most frequent perceived factors.

Two experiments had been done based on the specific questionnaires in the written form as quantitative analysis and verbal data analysis respectively by oral interviews. First experiment was conducted among 72 respondents in order to know the factors in case of purchasing gent's casual and/or moccasin shoes with preferred four factors and in the second experiment, feedbacks were taken from the participants after wearing sample shoes by them for the specified period of time span to evaluate the basic comfort properties of that categories of shoes. Data were collected through the answer of the prescribed fourteen multiple choice questions (M.C.Q) and in depth oral interview of the selected participants. Additional comments apart from the prescribed M.C.Q's were also accepted and considered. The survey questionnaires were prepared representing all the possible choosing factors and comfort properties of the casual and/or moccasin shoes to bring to light the real information what actually people thought before purchasing a pair of shoe. The sample questionnaires were categorized into three groups such as close-ended, preference and open-ended questions where most of the questions were open-ended. A preference ranking was established among the top four considered factors using participants' responses and represented graphically. Among the top four factors, frequency of the first preferred one was not counted during selecting the second preference and consequently the same process was followed for third and fourth preference, for example, when style was selected as first preference among the first four factors, it was omitted for second preference consideration but frequency of remaining three factors in case of first preference and second preference, were considered for selecting second preference and the same process was followed for third preference. The feedbacks from the sample population about comfort features were then analyzed through Pareto diagram in order to get most frequent factors. In the second part of this experiment, the aim of this research work was translated to four experts and feedbacks from respondents were shared through an open discussion session. A prescribed form with detail instructions was supplied to the experts for inputting their considered features regarding shoe purchasing decision factors and comfort features in a preferred way. Then in the second phase, only the factors which were considered by at least two experts were provided to make scoring again in order to attain frequently considered factors. An average weighted method was followed to bring out the most frequent factors and then analyzed the result with respondent's feedbacks.

\section{RESULTS AND DISCUSSION}

\section{Choice Factors Analysis}

The feedbacks from the survey regarding the choosing factors during purchasing shoes are depicted in Fig.1. Style was considered as the first priority factor at the time of purchasing shoes by the maximum participants and that was $91 \%$. The second highest factor, i.e., comfort was chosen by $90 \%$ of the sample population. Price was another criteria that was considered by $83 \%$ of the participants as third factor for choosing shoes at the time of purchasing. Color, outlook, brand, leather upper, durability, weight, matching, safety, outsole features, heel height and synthetic upper were rest of the factors to be considered during shoe purchase and these were recommended by $79 \%, 66 \%, 65 \%, 64 \%$, $61 \%, 55 \%, 45 \%, 41 \%, 29 \%, 23 \%$ and $13 \%$ of the experimental sample population respectively. The least number of participants, only $13 \%$ respondents considered synthetic upper materials as a comfort feature of shoe. 


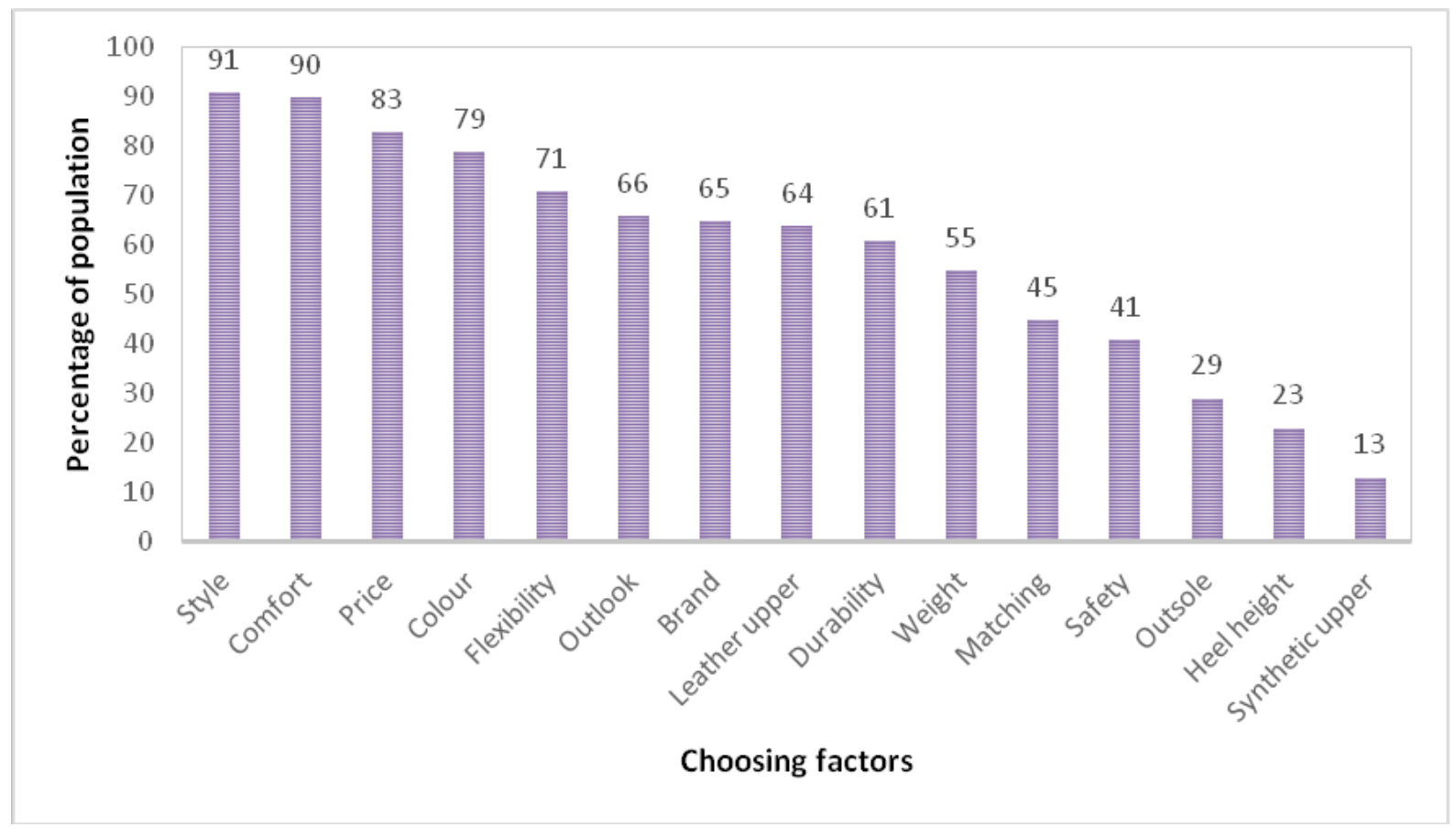

Figure 1. Percentage of choice factors during new shoe purchase

From the above analysis it can be observed that customers are fascinated at first by shoe's style rather than other important comfort features. After the style, they look for other properties of the shoes such as comfort, price, color, outlook, brand, leather upper, durability, weight, matching, safety, outsole, heel height and synthetic upper.

The other part of the first experiment was to prioritize the top four factors chosen by the participants from Fig.1, these factors are style, comfort, price and color accordingly.

\section{Style Comfort $\square$ Price $\quad$ Colour}

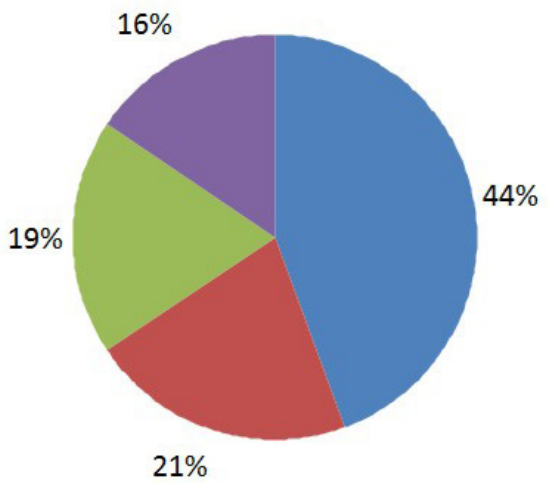

Figure 2. Style as first preference

\section{Comfort \\ Price \\ Colour}

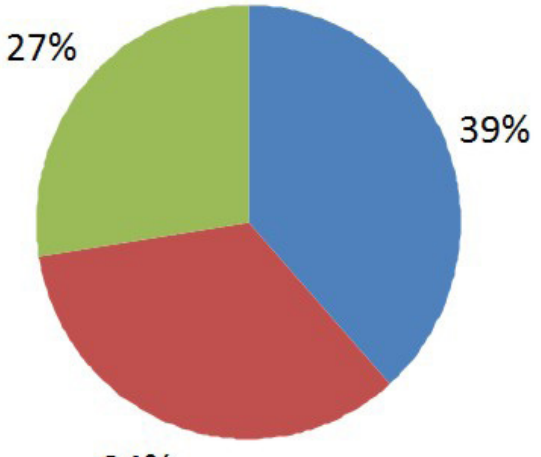

$34 \%$

Figure 3. Comfort as second preference

From Fig.2, it is seen that the highest number of participants (44\%) selected style as the first option according to their preference of choices. Comfort, price and color were chosen as first preference by $21 \%, 19 \%$ and $16 \%$ of the respondents particularly. Fig. 3 indicates that comfort property was chosen as a second priority factor by $38 \%$ frequency of the sample population whereas price and color were preferred as second priority factors by $34 \%$ and $28 \%$ of frequency proportionally. 


\section{Price Colour}

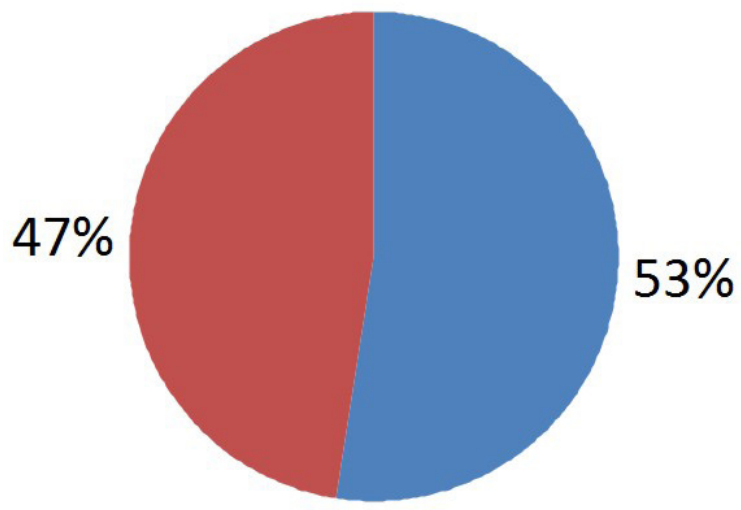

Figure 4. Price as third preference

After finding the first two preferred factors such as style and comfort, all frequency for the remaining two factors i.e., price and color from first to third preference were calculated to find the third preferred factor. In the Fig.4, the frequency for price (53\%) was found slightly higher than that for color (47\%). Since style, comfort and price were already observed as first, second, and third preferred factors respectively and therefore, the remaining factor color will be placed in fourth preference. From the above analysis, it can be summarized that customers considered shoe style firstly then comfort, price and finally color in case of choosing a pair of new shoe. The preference ranking can be depicted as style $>$ comfort $>$ price $>$ color.

\section{Verbal Data Analysis}

According to the participants' feedbacks, statements were interpreted at the same level of detail and these were analyzed where 72 respondents provided 252 comments regarding comfort properties of shoe and total number of comments under each factor were presented in Fig. 5.

In Figure 5 English capital letters from A

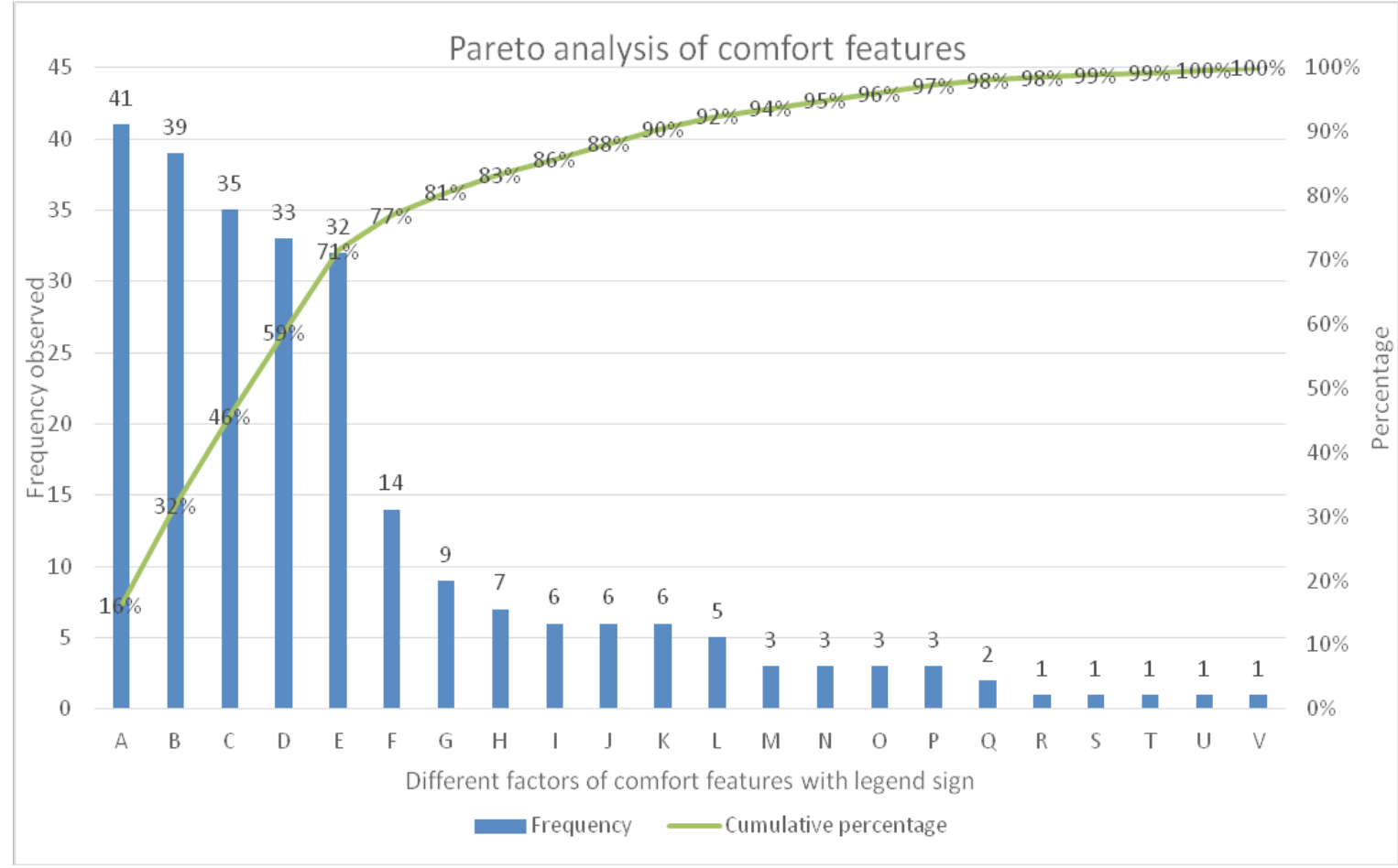

Figure 5. Pareto diagram for identified several comfort features by the respondents 
to $\mathrm{V}$ were used as legend in order to represent twenty two features such as breathability of upper and lining material (A), proper size and fit (B), light weight of the shoe (C), cushioning ability of insole (D), flexible upper material (E), good appearance of the shoe (F), avoidance of extra heel height $(G)$, leather upper and lining material $(H)$, avoiding internal friction inside the shoe (I), flexible outsole (J), durability of shoe (K), enough toe space (L), slip resistance of outsole $(\mathrm{M})$, padded top line $(\mathrm{N})$, water resistance of upper material (O), softy upper and lining material $(\mathrm{P})$, well-balanced toe spring and heel height $(Q)$, proper arch support $(R)$, softy Outsole (S), enough protection of shoe $(T)$, shock absorptivity of insock (U) and air trapping quality in winter season (V).

After analyzing these comments by Pareto diagram, generally known as $80 / 20$ principle whereas $20 \%$ of total factors are responsible for greater impact of the output and remaining $80 \%$ has the least influence over the result, it was observed that first six factors such as breathability (A), proper shoe size \& fit (B), light weight (C), cushioning ability (D), flexible upper materials (E), and good appearance of the shoe $(F)$, were mostly preferred to the experimental population. On the other hand, the rest of sixteen factors from $\mathrm{G}$ to $\mathrm{V}$ got less priority.

Breathability of upper and lining materials was considered by the highest number of participants (41) as the most important factor which makes the foot dry and prevents bad odor and bacterial growth inside the shoe. 39 of the participants mentioned proper size and fit as another comfort feature that ensures better fitting of the shoe and protects the foot from different foot ailments and injuries. The shoe should be light weight for more comfort and easy walking and this was also mentioned by the good number of experimental population. The cushioning ability and flexibility of shoe materials and whole shoe were addressed by the participants significantly whereas the appearance of the shoe was also considered among first six factors. Avoiding extra heel height, upper and lining material impact, avoiding internal friction, flexible outsole, durability, enough toe space, slip resistance, padded topline, water resistance, soft upper and lining, toe spring and heel height, arch support and other factors were considered by the least number of participants which signifies that most of the people have less perception on these factors before purchasing new shoes.

On the contrary, the participants who wore shoes made of synthetic upper material felt a high discomfort since this caused excessive perspiration and these shoes were less durable than leather shoes. Besides, participants who used pointed toe shoes, felt narrow fitting at the forepart region which caused extra pressure on the toes resulting blisters and pain in this area. Heavy weight of the shoe made the foot more tired at the time of walking, slow stepping and imparting muscles tension in the feet. Paying indispensability to the comfort factors of shoe, it can be summarized from this study that breathability of upper and lining material, flexibility of shoe, proper size and fit, light weight, enough shock absorption ability and optimum heel height of the shoe are the major comfort features according to participants' comments for any kind of shoe to be addressed before purchasing a pair of new shoe.

\section{Analysis of Experts' Data}

An average weighted method was conducted to get preferred purchasing factors and comfort features followed by four experts. A corresponding score for each factor was pursued 
by Table 1 and weight for particular factor was given by the experts' feedback. Then the average weighted method was resulted for disclosing the sequence of the factors for purchasing shoes and also for comfort features; depicted individually in Fig 6 and Fig 7.

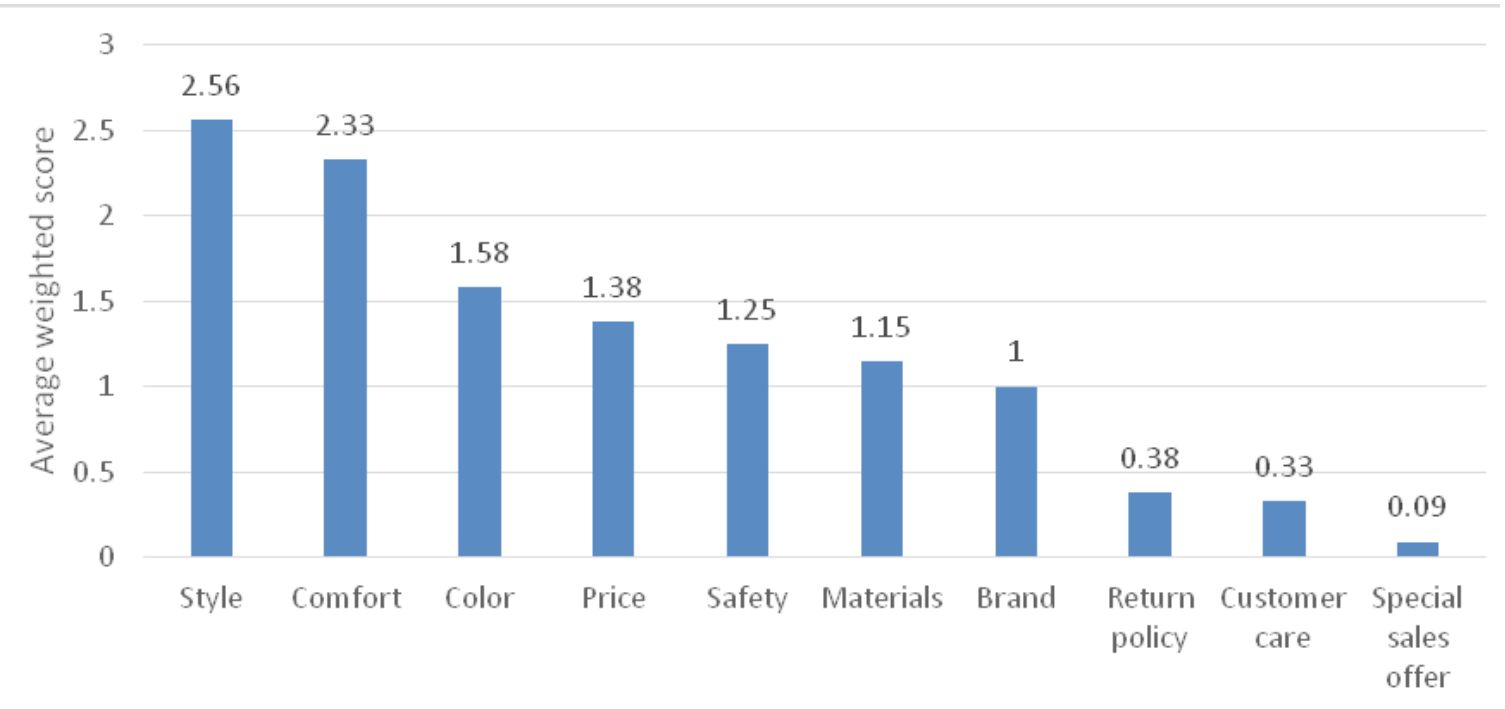

Different preferred purchasing factors

Figure 6. Different preferred purchasing factors suggested by four experts followed by average weighted method

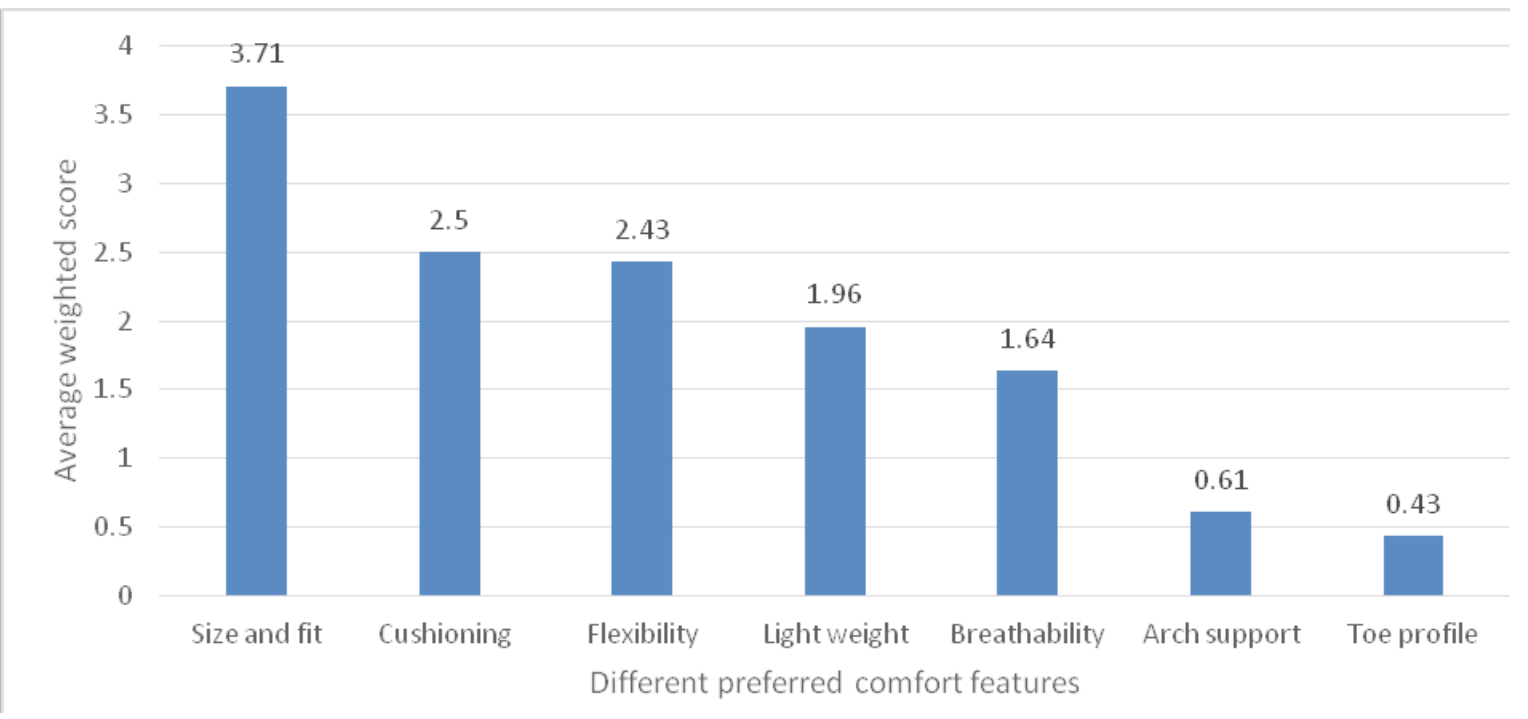

Figure 7. Frequently preferred comfort factors suggested by four experts followed by average weighted method 
Table 1: Linguistic terms for rating criteria

\begin{tabular}{lc}
\hline Linguistic terms & Corresponding score \\
\hline Very high influence & 4 \\
High influence & 3 \\
Medium influence & 2 \\
Low influence & 1 \\
No influence & 0 \\
\hline
\end{tabular}

Experts also have given priority to style and comfort that matches with the participants' choice. After comfort, experts preferred color, and then price whereas participants preferred price first and then color. Safety features, materials characteristics, brand value, goods return policy, customer care and special sales offer were then considered by them. The factors such as return policy, customer care and special sales offer were not identified in any previous literature but these have an indirect effect on shoe purchase.

In the second part of the experts' feedbacks, frequently comfort features were identified such as proper size and fit, cushioning ability of materials, flexibility of materials, light weight of the shoe, breathability of upper and lining materials, arch support and finally shape of the toe region of the shoe. Experts firstly consider proper size \& fit and breathability as fifth factor whereas participants suggested breathability first.

\section{Frequently Considered Common Comfort Fea- tures and their Implications}

\section{Size and Fit}

The inner length of a shoe which is dictated by the corresponding standard last (a mould on which the shoe is made) length is termed as shoe size while fit is the ability to conform to the size, width, shape and proportions of the foot. There are different sizing systems; such as UK system, Paris point, US system and Mondo Point. Loose fitting of shoe may cause inconvenient in walking and will not be comfortable. On the other hand, narrow fit in the forefoot region can engender foot deformations; such as blister, hallux valgus, hammer toe, bunions and other vulnerable problems [20-22].

\section{Cushioning Ability}

Cushioning ability can be defined as the capacity of a material to absorb shock and dispersed the shock along its area properly. The use of resilient materials, particularly as an insole or midsole which absorbs step shock and provides a comfort zone between the sole of the foot and the ground, is essential for cushioning features [23]. During walking, the back part of the foot known as heel area which strikes the ground first and thus it faces opposite force according to the Newton's third law. If the material of a shoe can absorb this shock and distribute it uniformly to its area, it will provide more comfort to the wearers.

\section{Flexibility of Materials}

As our foot flexes during walking in the forepart region at the joint of metatarsal heads, upper materials and sole should be compatible with this flexing and also materials should endure this flexing without any damages. Leather has strong tensile and tear strength which make it comfortable as suitable flexible material with high degree of endurance.

\section{Light-weightiness}

The more the weight of the shoe, it will hinder the movements of foot and causes tiredness to the feet. The lesser the weight, the more comfort will be found in walking. It is roughly recommended that a pair of shoe should not weigh more than $500 \mathrm{gm}$.

\section{Breathability}

Breathability is the ability of a material to permit vapor and air from inside the shoe to outer environment produced by sweat glands and inner frictions between foot and shoe. It is defined as the volume of permitting water vapor in unit time and unit area. This property 
is generally considered as the most important characteristic for comfort features of shoe which prevents the foot from getting wet and excessive perspiration. In the absence of this property; the feet produce bad odor which may cause skin irritation, skin-allergy and favorable conditions for bacterial growth.

\section{Arch Support}

Arch support can be defined as a rigid support placed inside a shoe so that its moulded form fits the inner longitudinal arch (the inside curvature of foot) which relieves strain on the muscles of the foot while walking, standing or any kind of movement. Support is provided through the design of the shank (a metal bar used between insole and sole), an orthotic insole (the bottom of shoe in which sole is attached), an arch cushion, or padding [23]. Shoes with good arch support ensure proper control of the foot and extra support for fascia ligament of the foot from being distorted.

\section{Toe Room Allowance}

In order to ensure proper fitting of a shoe toe room allowance is an important feature that will provide the space for the free movement of toes that is required for comfort of the shoe during wearing. Toe room allowance is generally considered $3 / 8$ inch to $1 / 8$ inch, from longest toe to the end of each shoe (source: The National Shoe Retailers Association, Pedorthic Footwear Association and American Foot and Ankle Society). If sufficient toe room allowance is not ensured, the foot will be in a compact position that will affect proper size \& fit and also cause narrow fitting that will cause severe discomfort.

\section{CONCLUSION}

This study has unveiled the most considered factors at the time of purchasing new shoes and also essential comfort features of gent's casual and/or moccasin shoes. Among many factors for choosing a pair of shoes, style has come out as the first priority factor that means customers are very fashionable and trendy. Comfort was the second factor that prevents our foot from different types of ailments and provides ease in walking; this factor signifies that customers always want comfort shoes. Though price is considered after style and comfort but it has a great influence over them. Retailers can focus on customer care, goods return policy and special sales offer which will influence the customers indirectly for purchasing shoes. On the other hand, customers should find proper size \& fit, cushioning, flexibility, light weight, breathability, arch support and toe room allowance for ensuring better comfort before purchasing shoes. Since leather has its unique porous structure, it is considered as high breathable natural material which was suggested as preferred material for shoe manufacturing. The upper part of shoes should be made of flexible light material to match the shape of one's foot and also for compatibility with different movements of feet. Materials of insole and sole should have enough cushioning ability that will provide shock absorbing property to the shoe which is a necessary feature for comfort shoes. Shoe manufacturers should pay proper focus on these customers' requirements and satisfy the preferred comfort features at optimum price point.

\section{Acknowledgement}

The author would like to give special thanks to Institute of Leather Engineering and Technology, University of Dhaka, for full funding for this research work.

\section{REFERENCES}

1. Vernon, W., Borthwick, A.M., Walker, J., Hardy, B., Dunning, D., Dentone, C., Drew, C., Nunn, M., Expert group criteria for the recognition of healthy footwear, British Journal of Podiatry, 2007, 10, 1, 27-33.

2. Directive 2008/121/EC of the European Parliament and of the council of 14th January 2009 on textile names (recast), Official Journal 
of the European Union, 2009, 19-48.

3. Zhang, L.J., Helander, M.G., Drury, C.G., Identifying Factors of Comfort and Discomfort in Sitting, Hum Factors, 1996, 38, 3, 377-389, https://doi. org/10.1518/001872096778701962.

4. Goonetilleke, R.S., The Comfort-Discomfort Phase Change, in International Encyclopedia of Ergonomics and Human Factors, W. Karwowski (Ed.), Taylor and Francis, 2001, 399-402.

5. Goonetilleke, R.S., Footwear Cushioning: Relating Objective and Subjective Measurements, Hum Factors, 1999, 41, 2, 241-256, https://doi. org/10.1518/001872099779591231.

6. Luximon, A., Goonetilleke, R.S., Tsui, K.L., A Fit Metric for Footwear Customization, Proceedings of the 2001 World Congress on Mass Customization and Personalization, October 1-2, 2001, Hong Kong (CD-ROM).

7. Witana, C.P., Feng, J., Goonetilleke, R.S., Dimensional Differences for Evaluating the Quality of Footwear Fit, Ergonomics, 2004, 47, 12, 1301-1317, https://doi.org/10.1080/ 00140130410001712645.

8. Ruto, E., Garrod, G., Investigating farmers' preferences for the design of agri-environment schemes: a choice experiment approach, J Environ Plann Man, 2009, 52, 5, 631-647, https://doi. org/10.1080/09640560902958172.

9. Au, E.Y., Goonetilleke, R.S., A qualitative study on the comfort and fit of ladies dress shoes, Appl Ergon, 2007, 38, 6, 687-696, https://doi. org/10.1016/j.apergo.2006.12.002.

10. Chaturvedi, S., Factors Influencing Preferences in Purchasing International Footwear Brand, Global Journal of Enterprise Information System, 2015, 7, 2, 19, https:// doi.org/10.18311/gjeis/2015/2963.

11. Ismail, Z.M.S., Factors Affecting Consumer Preferences of International Brands over Local Brands, 2nd International Conference on Social Science and Humanity IPEDR,
Singapore, 2012.

12. Vincent, H.K., Vincent, K.R., Five Key Characteristics to Consider when Purchasing a Running Shoe, Curr Sports Med Rep, 2015, 14, 5, 358, https://doi.org/10.1249/ JSR.0000000000000185.

13. Bowen, C., Ashburn, A., Cole, M., DonovanHall, M., Burnett, M., Robison, J., Mamode, L., Pickering, R., Bader, D., Kunkel, D., A survey exploring self-reported indoor and outdoor footwear habits, foot problems and fall status in people with stroke and Parkinson's, J Foot Ankle Res, 2016, 9, 1, 39, https://doi. org/10.1186\%2Fs13047-016-0170-5.

15. Fordzyun, Y.I., Graphically-Numerical Method of Comprehensive Assessment Hygienic Properties of Shoe Materials (in Ukrainian), Bulletin of KNUDT, 1, 2011, 239-243.

16. Fordzyun, Y.I., Andreyeva, O.A., Psychophysical aspect of discomfort feeling in the consumersfootwear-external environment system (in Ukrainian), Bulletin of KNUTD, 1, 2011, 132137.

17. Silvester, R.N., Williams, A.E., Dalbeth, N., Rome, K., Choosing shoes: A Preliminary Study into the Challenges Facing Clinicians in Assessing Footwear for Rheumatoid Patients, J Foot Ankle Res, 2010, 3, 1, 24, https://doi. org/10.1186/1757-1146-3-24.

18. Fordzyun, Y., Andreyeva, O., Maistrenko, L., Level of Comfort: Artificial and Natural Shoe Materials, A Comprehensive Assessment, Key Eng Mater, 2013, 559, 25-30 https:// doi.org/10.4028/www.scientific.net/ KEM.559.25.

19. Jordan, C., Payton, C.J., Bartlett, R.M., Perceived Comfort and Pressure Distribution in Casual Footwear, Clin Biomech, 1997, 12, 3, S5.

20. Snow, R.E., Williams, K.R., Holmes, G.B., The effects of wearing high heeled shoes on pedal pressure in women, Foot Ankle, 1992, 13, 2, 85-92.

21. Mandato, M.G., Nester, E., The effects of increasing heel height on forefoot peak 
pressure, J Am Podiatr Med Assoc, 1999, 89, 2, 75-80, https://doi.org/10.7547/8750731589-2-75.

22. Frey, C., Foot health and shoewear for women, Clin Orthop Relat Res, 2000, 372, 3244.

23. Rossi, W.A., The Complete Footwear Dictionary, Krieger Publishing Company, 2000, 4, 44.

(C) 2018 by the author(s). Published by INCDTPICPI, Bucharest, RO. This is an open access article distributed under the terms and conditions of the Creative Commons Attribution license (http:// creativecommons.org/licenses/by/4.0/). 